\title{
A THEORY OF TORT LIABILITY FOR SEXUAL HARASSMENT IN THE WORKPLACE
}

\author{
KRISTA J. SCHOENHEIDER $†$
}

Women have faced the problem of sexual harassment in the workplace ever since they entered the labor force. ${ }^{1}$ As a social, political, and legal term, sexual harassment is susceptible to a variety of definitions. ${ }^{2}$ It can describe conduct ranging from an "accidental" brushing against sylvania.

† A.B. 1984, Bryn Mawr College; J.D. Candidate 1987, University of Penn-

I See generally Goodman, Sexual Harassment: Some Observations on the Distance Travelled and the Distance Yet to Go, 10 GAP. U.L. REv. 445, 448-52 (1981) (discussing the history of sexual harassment in the United States). See also L. FARLEY, Sexual Shakedown: The Sexual Harassment of Women on the Job 56-68 (1980) (history of sexual harassment from the 1860's to the beginning of the modern labor movement).

This Comment focuses on the harassment of women by men because sexual harassment in the employment context is generally viewed as a problem faced exclusively by women: "[T]he common denominator is that the perpetrators tend to be men, the victims women." C. Mackinnon, Sexual Harassment of Working Women: A Case of Sex Discrimination 28 (1979). The analysis presented herein, however, could conceivably apply to sexual harassment of men by women, women by women, and men by men.

2 MacKinnon broadly defines sexual harassment as "the unwanted imposition of sexual requirements in the context of a relationship of unequal power." G. MAcKiNNON, supra note 1, at 1 . Farley's definition refers specifically to workplace harassment: "unsolicited nonreciprocal male behavior . . . that asserts a woman's sex role over her function as a worker." L. FARLEY, supra note 1, at 14. The Working Women's Institute provides a more precise definition:

Sexual harassment in employment is any attention of a sexual nature in the context of the work situation which has the effect of making a woman uncomfortable on the job, impeding her ability to do her work, or interfering with her employment opportunities. ... At one extreme, it is the direct demand for sexual compliance coupled with the threat of firing if a woman refuses. At the other, it is being forced to work in an environment in which, through various means, such as sexual slurs and/or the public display of derogatory images of women or the requirement that she dress in sexually revealing clothing, a woman is subjected to stress or made to feel humiliated because of her sex. Sexual harassment is behavior which becomes coercive because it occurs in the employment context, thus threatening both a woman's job satisfaction and security.

Working Women's Institute, Sexual Harassment on the Job: Questions and Answers 180 (unpublished manuscript on file with the University of Pennsylvania Law Review); accord Vermeulen, Comments on the Equal Employment Opportunity Commission's Proposed Amendment Adding Section 1604.11, Sexual Harassment, to Its Guidelines on Sexual Discrimination, 6 Women's RTs. L. REP. 285 (1980). Compare this definition with the narrower one presented in the Guidelines of the Equal Employment Opportunity Commission (E.E.O.C.), infra text accompanying note 42 . 
a woman's body or an unwanted touching or kissing to a physical assault $^{3}$ such as rape. ${ }^{4}$ Sexual harassment also assumes verbal forms, such as suggestive remarks or derogatory comments ${ }^{5}$ or direct demands for sex. $^{6}$

Sexual harassment has a devastating effect on both the economic opportunities and the physical and emotional well-being of working women. ${ }^{7}$ Although sexual harassment constitutes employment discrimination under Title VII of the Civil Rights Act, legal protection against harassment remains grossly inadequate. Because Title VII remedies are primarily injunctive, they fail to compensate fully for the severe personal harm inflicted upon most victims. ${ }^{8}$ Punitive damages, which can impose a powerful deterrent on an offending party, are also unavailable. ${ }^{\circ}$

With the exception of some state antidiscrimination laws, ${ }^{10}$ tort law is the only body of law that provides a private remedy for personal harm caused by sexual harassment; moreover, only tort law allows the victim to receive an award of punitive damages when appropriate. In its present form, however, tort law fails to deal with the full effects of harassment on the individual victim. ${ }^{11}$ In the absence of at least a threat of physical injury or other conduct a court deems to be suffi-

s See, e.g., Tomkins v. Public Serv. Elec. \& Gas Co., 422 F. Supp. 553 (D.N.J. 1976), rev'd, 568 F.2d 1044 (3d Cir. 1977) (employer physically restrained plaintiff and threatened her with harm if she did not comply with his sexual demands).

- See C. MacKinnon, supra note 1, at 2, 29; Andrews, The Legal and Economic Implications of Sexual Harassment, 14 N.C. CENT. L.J. 113, 119 (1983).

B See, e.g., Kyriazi v. Western Elec. Co., 461 F. Supp. 894, 934 (D.N.J. 1978) (male coworkers "made bad remarks concerning [plaintiff's] marital status, and trumpeted their speculations and even made wagers concerning [plaintiff's] virginity").

B See, e.g., Tomkins, 568 F.2d at 1045.

7 See infra notes $39-83$ and accompanying text.

See infra notes 78-80 and accompanying text.

- See infra notes 81-82 and accompanying text.

10 See, e.g., Mich. CoMp. Laws ANN. $\$ 37.2801$ (West 1985) (authorizing private action for damages for violations of state antidiscrimination laws); MINN. STAT ANN. § 363.071 (West 1986) (examiner in employment discrimination hearing authorized to "order [employer] to pay an aggrieved party, who has suffered discrimination, compensatory damages"); WIS. STAT. ANN. §111.39(c) (West 1985) (if examiner finds that employer has engaged in discrimination, she may order payment of damages to plaintiff). In fact, certain state antidiscrimination statutes provide exclusive remedies. See, e.g., Mass. Gen. Laws ANN. ch. 151B, $\S 9$ (West 1976) (If petitioner files civil action for damages or injunctive relief, any complaint pending before state commission is "dismissed without prejudice."); PA. STAT. ANN. tit. 43, § 962(b) (Purdon 1986) (procedure under state Human Relations Act is "exclusive and the final determination therein shall exclude any other action, civil or criminal, based on the same grievance of the complaint concerned." A complainant who "institutes any action based on such grievance without resorting to the procedure provided in this Act . . . may not subsequently resort to the procedure herein."); see also infra note 89.

${ }^{11}$ See infra notes 100-42 and accompanying text. 
ciently "outrageous," a plaintiff can rarely rely on traditional tort theories for adequate compensation.

This Comment argues that Title VII, as presently interpreted by the federal courts, fails to redress fully the severe emotional and physical harm caused by sexual harassment in the workplace. Furthermore, the rigidity of state tort law generally prevents a harassment victim from recovering damages when her harm truly deserves compensation. In view of the inadequacies of existing law, this Comment proposes that courts recognize an independent cause of action in tort for sexual harassment in the employment context. By offering a legal remedy for a worker's personal harm and a deterrent in the form of punitive damages, a tort theory directed specifically at workplace harassment would provide an important supplement to the equitable remedies presently available under federal employment discrimination law.

Part I of this Comment details sexual harassment's adverse effects on working women. Part II outlines and questions the effectiveness of the remedies made available to harassment victims through Title VII of the Civil Rights Act. Part III provides a similar analysis of the remedies available under traditional tort law. Finally, Part IV proposes an alternate tort claim for sexual harassment that, if implemented, would result in adequate recovery for plaintiffs and an effective deterrent to harassment in the workplace.

\section{Sexual Harassment and its Effects on Working Women}

Generally, harassment can be classified into two groups: "quid pro quo" and "absolute" harassment. Quid pro quo or tangible harassment occurs when an employer or supervisor conditions a job benefit or continued employment on the employee's compliance with sexual demands. ${ }^{12}$ For example, ${ }^{13}$ during a business lunch at which an office worker and her employer are discussing the employee's future promotion, the employer suddenly makes sexual advances. When the employee rejects her employer's propositions, he attempts to physically restrain her from leaving the table. Soon afterward, the office worker is threatened with physical harm, demoted, and eventually fired.

In contrast to quid pro quo harassment, absolute-or intangible-harassment involves no threat to a concrete job benefit ${ }^{14}$ but in-

12 See Note, Employer Liability for Coworker Sexual Harassment Under Title VII, 13 N.Y.U. Rev. L. \& Soc. Change 83, 85 (1984-85).

13 This example comes from Tomkins v. Public Serv. Elec. \& Gas Co., 422 F. Supp. 553 (D.N.J. 1976), rev'd, 568 F.2d 1044 (3d Gir. 1977).

14 See Note, supra note 12 , at 87. 
stead creates a hostile work environment through unwanted, sexually offensive conduct. ${ }^{15} \mathrm{~A}$ lobby attendant whose sexually revealing uniform attracts comments, gestures, and propositions from passersby experiences intangible sexual harassment. ${ }^{16}$ Similarly, a female industrial engineer becomes a victim of intangible harassment when colleagues bombard her with sexual jokes, make remarks about her marital status and virginity, and draw an obscene cartoon to humiliate her. ${ }^{17}$

As the previous examples of intangible harassment illustrate, an employer is not the exclusive source of sexual harassment in the workplace. Co-employees ${ }^{18}$ and nonemployees, such as business clients, restaurant customers, and the general public, also subject women to harassment in the employment context. ${ }^{19}$

Sexual harassment has a devastating impact on the individual worker. Victims suffer from insomnia, depression, nervousness, and other symptoms of psychological harm, ${ }^{20}$ sometimes leading to a complete emotional breakdown. ${ }^{21}$ The physical effects of harassment include headaches, backaches, nausea, loss of appetite, weight change, and fatigue. ${ }^{22}$ Harassment clearly poses a serious threat to an employee's physical and mental well-being:

\section{The anxiety and strain, the tension and nervous exhaustion}

15 See Meritor Sav. Bank v. Vinson, 106 S. Ct. 2399, 2404-05 (1986) (recognizing "hostile environment" harassment as sex discrimination where the conduct interferes with a person's work performance or creates a sexually offensive work environment).

${ }_{16}$ See E.E.O.C. v. Sage Realty Corp., 507 F. Supp. 599, 604-06 (S.D.N.Y. 1981).

17 See Kyriazi v. Western Elec. Co., 461 F. Supp. 894, 934 (D.N.J. 1978).

18 See Vermeulen, supra note 2, at 287 ("Peers can exert tremendous power over a woman's ability to remain on the job. They can sabotage work directly and indirectly. Even absent such overt undermining efforts, peers can render the work environment so tense, intolerable, and hostile that a woman is forced to leave the job.").

10 See id. (stating that "clients and customers are also a frequent source of sexual harassment. . . Harassment from this sector is similar in its impact to harassment from coworkers."); see also C. MAcKINNON, supra note 1, at 44 (discussing the subjection of waitresses to propositions and unwanted touching).

${ }^{20}$ A study published by the Working Women's Institute revealed that $96 \%$ of harassment victims showed psychological symptoms such as fear, nervousness, anger, and feelings of powerlessness, and that $12 \%$ of these victims were forced to seek therapy. See Crull, The Impact of Sexual Harassment on the Job: A Profile of the Experiences of 92 Women. WORKING WOMEN'S InSTITUTE RESEARCH SERIES, REPORT No. 3, at 4 (1979) [hereinafter W.W.I. Report No. 3]; see also C. BrodSKY, ThE HARASSED WORKER 40 (1979) (discussing the psychological effects of harassment).

${ }^{21}$ See, e.g., Gates v. Brockway Glass Co., 93 L.R.R.M. (BNA) 2367 (C.D. Cal. 1976) (harassed female worker unable to work because of emotional breakdown), cited in C. MacKinnoN, supra note 1 , at 50.

${ }_{22}$ Sixty-three percent of the participants in the Working Women's Institute study experienced these physical effects of sexual harassment. W.W.I. REPORT No. 3, supra note 20, at 4; see also C. BRodsKy, supra note 20, at 40; C. MACKINNON, supra note 1 , at 51 (discussing a harassed worker who experienced severe pain in her arms and neck until she left her job). 
that accompany this kind of harassment take a terrific toll on women workers. Nervous tics of all kinds, aches and pains (which can be minor and irritating or can be devastatingly painful) often accompany the onset of sexual harassment. These pains and illnesses are the result of insoluble conflict, the inevitable backlash of the human body in response to intolerable stress which thousands of women must endure in order to survive. ${ }^{23}$

In addition, harassment on the job hinders a woman's chances of economic advancement. The conflict and stress that a harassed worker faces every day inevitably interferes with her job performance. At worst, she will be fired for refusing to submit to sexual demands, or she will be forced to resign because of offensive or hostile working conditions. ${ }^{24}$ Even if she does not leave her job, the time and energy that she must devote to dealing with harassment will certainly affect her performance at work. ${ }^{28}$ Encounters with harassment reduce an employee's motivation and desire for career advancement, ultimately discouraging her from seeking promotions or positions in traditionally male-dominated fields. ${ }^{2 B}$

Collectively, the social and economic consequences of sexual harassment are quite severe. As both a form of discriminatory behavior and a source of economic harm to women, harassment becomes a type of employment discrimination. Sexual harassment reinforces the economic subordination of women workers. Traditional employment patterns have confined women to inferior jobs and restricted their opportunities for advancement. ${ }^{27}$ The practice of sexual harassment is

2s L. Farley, Testimony before Commission on Human Rights of the City of New York, Special Disadvantages of Women in Male-Dominated Work Settings 6 (April 21, 1975), quoted in C. MACKInNON, supra note 1, at 52.

${ }_{24}$ Sixty-six percent of the respondents to the Working Women's Institute's questionnaire were either fired or pressured into resigning. See W.W.I. REPORT No. 3, supra note 20, at 4; see also Goodman, supra note 1, at $456 \mathrm{n.75}$ (discussing sexual harassment cases in which the female worker had been fired or forced to resign).

${ }^{28}$ See Vermeulen, supra note 2 , at 288.

20 See id. at 287. Eighty-three percent of the participants in the Working Women's Institute study felt that sexual harassment interfered with work, and they experienced a loss of self-confidence and desire to be successful. W.W.I. REPORT No. 3 , supra note 20 , at 4 .

27 See Women Employed, Employment Patterns: A Study of Discrimination and Remedies, in WOMEN IN THE ECONOMY 41 (1978). Horizontal segregation confines women to undesirable jobs involving "low interest or complexity, repetition and tediousness, little potential for self-direction, predominantly service-oriented, high contact with customers, involvement with children, and keeping things clean." C. MACKINNON, supra note 1 , at 11 . Vertical segregation forces women to become subordinates of men, who are authorized to do the "hiring, firing, supervising and promoting of women." Id. at 12. 
ultimately an expression of dominance, serving to perpetuate women's positions in "low paying and dead-end jobs." not limited to the conduct of employers and supervisors; often a male coworker has a considerable amount of indirect power over female employees. ${ }^{2 \theta}$

In addition, harassment ultimately causes severe economic harm to women as a group. Although the extent of this harm is difficult to measure precisely, observable consequences include increased unemployment and absenteeism, ${ }^{30}$ obstacles to promotions and seniority, ${ }^{31}$ lower income from lost earnings, a generally lower level of productivity, ${ }^{32}$ and substantial limitations to free choice within the scope of employment. ${ }^{33}$ The cycle of subordination and economic harm demonstrates that sexual harassment both relies upon and maintains "women's structurally inferior status."

Despite the psychological, physical, economic, and societal damage caused by sexual harassment, the development of a theory of liability and legal remedy for its harm has been slow and unsatisfactory. In early court cases, victims had to rely on traditional tort doctrines for relief. $^{35}$ As critics $^{36}$ during the 1970 's pointed out, however, tort law

28 Andrews, supra note 4, at 165; see also C. MAcKinnon, supra note 1, at 9-10 (arguing that women traditionally have occupied inferior positions and that sexual harassment "works to keep women in such positions").

${ }^{29}$ For example, a male coworker may have greater seniority or experience or be more familiar with supervisors. See Andrews, supra note 4 , at 166 . Sex role conditioning plays a major part in coworker harassment as well. See $i d$.

30 See Andrews, supra note 4, at 168; Goodman, supra note 1, at 456.

31 See Andrews, supra note 4, at 166 n.376.

s2 See id. at 167; Goodman, supra note 1, at 456, 466; Vermeulen, supra note 2, at 285-88. Lowered productivity and inefficiency are natural results of factors such as absenteeism and the physical and psychological consequences of harassment. See supra notes $20-23$ and accompanying text.

${ }_{38}$ Sex discrimination adversely affects a female employee's free choices and opportunity costs with respect to experience, training, and selection of an occupation. In particular, harassment limits free choice when submission to sexual advances becomes a condition of receiving job benefits. See Andrews, supra note 4, at 168-69 (citing C. Lloyd \& B. Niemi, The Economics of Sex Differentials 3-5 (1979)) (presenting a theory of sex discrimination from the perspective of free choices and opportunity costs).

s4 C. MACKInNoN, supra note 1, at 9-10.

s5 Early tort law provided "civil redress for sexual invasion at a time when social morality was less ambiguous in defining a woman's sexuality as intrinsic to her virtue, and her virtue as partially constitutive of her value, hence as capable of compensable damage." C. MACKINNON, supra note 1 , at 164 . Such cases generally focused on the element of physical force in the harassment of women who, for the most part, were not employed. Under the theories of battery, assault, and "indecent assault," courts granted monetary relief to women for "offensive touching," Hough v. Iderhoff, 69 Or. 568, 139 P. 931 (1914), and unwanted kissing, Liljegren v. United Sys. Co., 227 S.W. 925 (Mo. Ct. App. 1921) (railroad held responsible for drunken man falling on top of woman and kissing her on the cheek); Graker v. Chicago \& N.W. Ry., 36 Wis. 657, 659 
failed to address harassment as a pervasive social evil arising from the widespread notion that female employees were inferior to male employees. ${ }^{37}$ Due in large part to the efforts of these legal critics, courts finally have begun to treat sexual harassment not merely as an affront to an individual's self-esteem but rather as a devastating form of discrimination in violation of Title VII of the Civil Rights Act of 1964 (Title VII). ${ }^{38}$

(1875) (railroad conductor found liable for grabbing and forcibly kissing young female schoolteacher). Plaintiffs often could not recover for mental anguish unless the harm had been intentional or the defendant's conduct had been "wanton." See, e.g., Martin v. Jensen, 113 Wash. 290, 294-95, 193 P. 674, 676 (1920) (recovery for mental anguish alone only allowed where suffering "is the result of a wanton or intentional trespass on the person of a woman").

Skousen v. Nidy, 90 Ariz. 215, 367 P.2d 248 (1961), was one of the first cases that seemed to accept the notion that sexual harassment was unlawful not because it diminished a woman's "value," but rather because it harmed her physically, mentally, and economically. In Skousen, a female trailer park caretaker brought an action against her employer for assault and battery. He had repeatedly attempted to seduce her by touching her in a sexual manner and, on several occasions, assaulting her violently. See id. at 216-17, 367 P.2d at 249. In upholding an award for compensatory and punitive damages, the Arizona Supreme Court recognized the need to provide relief for the emotional harm caused by sexual harassment. See $i d$. at 218, 367 P.2d at 250 ("Mental suffering, including shame from the indignities of the acts, is usually considered an injury for which damages may be given.").

so See, e.g., L. FARLEY, supra note 1; C. MACKINNON, supra note 1. The publication of studies and responses to questionnaires also brought attention to the problem of sexual harassment on the job. See, e.g., Safran, What Men Do to Women on the Job: A Shocking Look at Sexual Harasment, REDBook, Nov. 1976, at 49; W.W.I. REPORT No. 3, supra note 20.

s7 See C. MacKinnon, supra note 1 , at 171-74.

ss 42 U.S.C. $\S 2000(e)-2000(e)(17)$ (1982). The earliest case in which a federal district court held that quid pro quo harassment violated Title VII was Williams v. Saxbe, 413 F. Supp. 654 (D.D.C. 1976), rev'd on other grounds and remanded sub nom. Williams v. Bell, 587 F.2d 1240 (D.C. Gir. 1978), on remand Williams v. Civiletti, 487 F. Supp. 1387 (D.D.C. 1980). After Williams, several previously unsuccessful suits in lower courts were reversed on appeal. See, e.g., Tomkins v. Public Serv. Elec. \& Gas Co., 422 F. Supp. 553 (D.N.J. 1976), rev'd, 568 F.2d 1044 (3d Cir. 1977); Miller v. Bank of America, 418 F. Supp. 233 (N.D. Cal. 1976), rev'd and remanded, 600 F.2d 211 (9th Cir. 1979); Garber v. Saxon Indus., 14 Empl. Prac. Dec. (CCH) 4896 (E.D. Va. 1976), rev'd and remanded sub nom. Garber v. Saxon Business Prods., 552 F.2d 1032 (4th Cir. 1977); Corne v. Bausch \& Lomb, Inc., 390 F. Supp. 161 (D. Ariz. 1975), vacated and remanded, 562 F.2d 55 (8th Gir. 1977); Barnes v. Train, 13 Fair Empl. Prac. Cas. (BNA) 123 (D.D.C. 1974), rev'd and remanded sub nom. Barnes v. Costle, 561 F.2d 983 (D.C. Cir. 1977).

Courts have only recently recognized intangible harassment as a form of employment discrimination. See, e.g., Katz v. Dole, 709 F.2d 251, 254 (4th Cir. 1983) (plaintiff subjected to sexual slurs, insults and innuendos, and other verbal harassment that "took the form of extremely vulgar and offensive sexually related epithets"); Henson v. City of Dundee, 682 F.2d 897, 899, 904 (11th Cir. 1982) ("harangues of demeaning sexual inquiries and vulgarities throughout the course of [employment]" were "sufficiently pervasive so as to alter the conditions of employment and create an abusive working environment," thereby giving rise to a cause of action under Title VII); Bundy v. Jackson, 641 F.2d 934, 943 (D.C. Cir. 1981) (employers violate Title VII if they 


\section{Sexual Harassment as Employment Discrimination UNDER TITLE VII}

\section{A. Title VII Standards and Remedies}

The federal courts have recognized sexual harassment as a form of employment discrimination violative of Title VII of the Civil Rights Act of $1964 .^{39}$ Although Title VII does not specifically refer to sexual harassment, the Guidelines of the Equal Employment Opportunity Gommission (Guidelines or E.E.O.C. Guidelines) ${ }^{40}$ define illegal harassment in the workplace and outline the scope of employer liability. Through interpretations of Title VII and the E.E.O.C. Guidelines, federal courts have established the current standard of liability and relief for sexual harassment.

\section{What Constitutes Sexual Harassment}

Under Title VII, an employer may not "fail or refuse to hire or . . . discharge any individual or otherwise . . . discriminate against any individual with respect to . . compensation, terms, conditions, or privileges of employment because of such individual's . . . sex." ${ }^{\text {"41 }}$ The E.E.O.C. Guidelines, published in 1980, explicitly classify sexual harassment as unlawful discrimination under Title VII. ${ }^{42}$ These guidelines provide the following definition of sexual harassment:

Unwelcome sexual advances, requests for sexual favors, and other verbal or physical conduct of a sexual nature constitute sexual harassment when (1) submission to such conduct is made either explicitly or implicitly a term or condition of an individual's employment, (2) submission to or rejection of such conduct by an individual is used as the basis for em-

\footnotetext{
"create . . . or condone . . . a substantially discriminatory work environment, regardless of whether the complaining employees [lose] any tangible job benefits"); Robson v. Eva's Super Market, Inc., 538 F. Supp. 857, 861 (N.D. Ohio 1982) (record contained "abundant evidence" from which court could find that employer's conduct created an intimidating, hostile, or offensive work environment). The Supreme Court recently held that such harassment is a violation of Title VII. See Meritor Sav. Bank v. Vinson, 106 S. Ct. 2399 (1986).

39 See supra note 38 and accompanying text.

so 29 C.F.R. \& 1604.11 (1986).

442 U.S.C. $\S 2000$ (e)-2(a)(1) (1982). Under Title VII, an "employer" is defined as "a person engaged in an industry affecting commerce who has fifteen or more employees . . . and any agent of such a person ...." 42 U.S.C. $\S 2000(e)(b)$ (1982).

62 29 C.F.R. § 1604.11(a) (1986). The Equal Employment Opportunity Commission is charged with enforcing the nation's equal employment laws. See 42 U.S.C. $\S$ 2000(e)-5 (1982).
} 
ployment decisions affecting such individual, or (3) such conduct has the purpose or effect of unreasonably interfering with an individual's work performance or creating an intimidating, hostile, or offensive working environment. ${ }^{43}$

Thus, the E.E.O.C. Guidelines' definition encompasses both quid pro quo and intangible harassment. ${ }^{44}$ The Guidelines also outline a process for determining whether certain forms of conduct constitute illegal harassment: "[T]he Commission will look at the record as a whole and at the totality of the circumstances, such as the nature of the sexual advances and the context in which the alleged incidents occurred."45 This language suggests that under certain circumstances a finding of sexual harassment could result even from "isolated, sporadic, or insulting incidents." 48

As interpretive rules issued by an administrative agency, the E.E.O.G. Guidelines are entitled to considerable deference ${ }^{47}$ but do not constitute binding rules of substantive law. ${ }^{48}$ Although courts have recognized both "quid pro quo" and intangible harassment as violations of Title VII, the judicial standard that most courts apply is stricter than that proposed in the Guidelines. For example, while the Guidelines leave open the possibility that a single incident could constitute sexual harassment, courts have required a showing of a pattern of harassment." An isolated incident is too "trivial"; the conduct must be "sufficiently severe or pervasive 'to alter the conditions of [the victim's] employment and create an abusive working environment." "150

According to some lower court cases, even a consistent pattern of offensive conduct or speech is not necessarily actionable. In Rabidue $v$. Osceola Refining Co., ${ }^{\text {s1 }}$ for example, a federal district court determined

4s 29 C.F.R. § 1604.11(a) (1986).

4t The requirement of sexual compliance as a "term or condition of an individual's employment," id., or "basis for employment decisions affecting such individual," id., constitutes quid pro quo, or tangible, harassment. Interference with work performance or the creation of an "intimidating, hostile, or offensive working environment," id., refers to absolute, or intangible, harassment. See supra notes 12-17 and accompanying text.

4s 29 C.F.R. § 1604.11(b) (1986).

4 Note, supra note 12 , at 95.

17 See Griggs v. Duke Power Co., 401 U.S. 424, 433-34 (1971).

18 See General Elec. v. Gilbert, 429 U.S. 125, $141-42$ (1976); see also Meritor Sav. Bank v. Vinson, 106 S. Ct. 2399, 2405 (1986).

19 See, e.g., Katz v. Dole, 709 F.2d 251, 254-55 (4th Cir. 1983); Henson v. City of Dundee, 682 F.2d 897, 904-05 (11th Cir. 1982); Bundy v. Jackson, 641 F.2d 934, 943-46 (D.C. Cir. 1981). Cf. Rogers v. E.E.O.C., 454 F.2d 234, 238 (5th Cir. 1971) cert. denied, 406 U.S. 957 (1972) (finding discrimination by national origin).

so Meritor, 106 S. Ct. at 2406 (quoting Henson, 682 F.2d at 904).

61584 F. Supp. 419 (E.D. Mich. 1984). 
that the vulgar language habitually used by the plaintiff's male supervisor, even when combined with the display of sexually explicit posters of women by her male coworkers, did not constitute a hostile or offensive working environment for the sole female employee in the office. The court concluded that the supervisor's language, while "annoying," was not "so shocking or severe as to actually affect a female worker's psyche." 12 As for the coworkers' posters, the court stated: "For better or for worse, modern America features open displays of written or pictorial erotica. . . . Living in this milieu, the average American should not be legally offended by sexually explicit posters." ${ }^{\text {"53 }}$ The Rabidue court apparently assumed that whether such posters appeared on the front of a movie theater or whether they were displayed on the walls of an office in which one woman had to work with several men, the effect on women would be the same.

\section{Standard of Employer Liability}

Under Title VII, only employers may be held liable for sexual harassment in the workplace, regardless of the identity of the actual harasser." The E.E.O.C. Guidelines impose a "constructive knowledge" standard on the employer for harassment by coworkers and nonemployees, so that liability arises only if the employer knew or should have known of the harassment. ${ }^{\mathrm{ss}}$ For the conduct of agents and supervisory employees, however, the Guidelines recommend a standard of strict liability, irrespective of employer knowledge. ${ }^{58}$ In fact, the agent or supervisor does not have to act affirmatively at all to be liable. Often the plaintiff may simply show that a supervisor acquiesced in the behavior of coworkers. ${ }^{.87}$

Judicial adherence to these guidelines has been inconsistent and is likely to remain so after Meritor Savings Bank $v$. Vinson. ${ }^{58}$ With respect to liability for harassment by coworkers and nonemployees, courts generally have followed the E.E.O.C. Guidelines by requiring that a

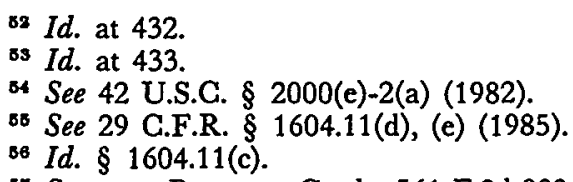

s7 See, e.g., Barnes v. Costle, 561 F.2d 983, 993 (D.C. Cir. 1971) (footnote omitted) ("[G]enerally speaking, an employer is chargeable with Title VII violations occasioned by discriminatory practices of supervisory personnel."); Robson v. Eva's Super Market, Inc., 538 F. Supp. 857, 863 (N.D. Ohio 1982) ("[A]n employer or supervisor may be held liable for employment discrimination where the employer or supervisor acquiesces or condones unlawful acts practiced by subordinates.").

s8 106 S. Ct. 2399 (1986). 
plaintiff prove either actual or constructive knowledge on the part of the employer. ${ }^{69}$ Courts also have conformed to the E.E.O.C. Guidelines by holding employers strictly liable for quid pro quo harassment by supervisors or agents, regardless of a company policy against discrimination or an internal grievance procedure. ${ }^{60}$

Courts have been divided, however, over the standard of employer liability for intangible harassment by a supervisor. In Vinson v. Taylor, ${ }^{61}$ the District of Columbia Circuit adhered to the E.E.O.G. Guidelines by holding an employer strictly liable for a supervisor's intangible harassment. The plaintiff, a bank teller-trainee, claimed that her supervisor, a vice-president of the bank, had forced her to have sexual relations with him. In addition to demanding sexual favors, the supervisor frequently caressed the trainee and exposed himself to her. The bank ultimately discharged the plaintiff for excessive use of sick leave. ${ }^{62}$

Although the district court dismissed Vinson's claim, ${ }^{63}$ the District of Columbia Circuit held that the bank would be liable for the hostile work environment created by the supervisor's conduct. The bank's liability would not be affected by the fact that the bank's higher management had no knowledge of the supervisor's behavior:

Instead of providing a reason for employers to remain oblivious to conditions in the workplace, we think the enlightened purpose of Title VII calls for an interpretation cultivating an incentive for employers to take a more active role in warranting to each employee that he or she will enjoy a working environment free from illegal sex discrimination. ${ }^{\text {B4 }}$

In contrast to this approach, the Eleventh Circuit has refused to hold an employer liable for intangible harassment committed by a supervisor unless the plaintiff can prove that the employer knew or should have known of the supervisor's conduct. ${ }^{65}$ The employee would be able to demonstrate such knowledge by showing that she had com-

so See, e.g., Katz v. Dole, 709 F.2d 251, 256 (4th Cir. 1983) (Plaintiff has to demonstrate that the "employer knew or should have known of the harassment."); Henson v. City of Dundee, 682 F.2d 897, 905 (11th Cir. 1982) (Plaintiff must show that the "employer knew or should have known of the harassment in question.").

${ }^{60}$ See, e.g., Miller v. Bank of America, 600 F.2d 211, 213 (9th Cir. 1979) (employer bank liable in Title VII suit for discriminatory firing by plaintiff's supervisor even though "the bank had an established policy against what . . . supervisor did").

753 F.2d 141 (D.C. Cir. 1985), aff'd in part, rev'd in part sub nom. Meritor

Sav. Bank v. Vinson, 106. S. Ct. 2399 (1986).

-2 See id. at 143.

6s See Vinson v. Taylor, 23 Fair Empl. Prac. Cas. (BNA) 37, 42 (D.D.C. 1980).

ot Vinson v. Taylor, 753 F.2d at 151.

os See Henson v. City of Dundee, 682 F.2d 897, 905 (11th Cir. 1982) (citing Bundy v. Jackson, 641 F.2d 934, 943 n.8 (D.C. Cir. 1981)). 
plained to upper management about the harassment. She could also show that the harassment was so pervasive that the employer had or should have known of the discrimination. ${ }^{66}$

In Meritor Savings Bank $v$. Vinson, ${ }^{67}$ the Supreme Court made tentative steps toward resolving this conflict. Although the Court declined to issue a "definitive" rule on employer liability, it concluded that neither strict liability nor constructive knowledge provided a satisfactory standard in cases of intangible harassment. Instead, trial courts should look to "agency principles" for guidance. ${ }^{68}$ Most importantly, perhaps, the Court refused to endorse the E.E.O.C. Guidelines' approach to such cases. The continued viability of the Guidelines may now be open to question. ${ }^{69}$

\section{Relief Under Title VII}

When an employer is held liable for unlawful sex discrimination, Title VII authorizes the court to enjoin the employer from practicing discrimination and to "order such affirmative action as may be appropriate, which may include, but is not limited to, reinstatement or hiring of employees, with or without back pay . . . or any other equitable relief as the court deems appropriate." ${ }^{\text {"7o }}$ Additionally, an award of a "reasonable attorney's fee" lies within the court's discretion." These remedies are intended to further the two primary objectives of Title VII: to eliminate employment discrimination, and to "make persons whole for injuries suffered on account of unlawful discrimination."72

\footnotetext{
68 See id.

B7 106 S. Ct. 2399 (1986)

68 See id. at 2408.
}

${ }^{68}$ The Equal Employment Opportunity Commission itself seems to have reconsidered its adherence to the E.E.O.C. Guidelines' standards for supervisor harassment. In Vinson, the E.E.O.C. filed an amicus brief proposing a standard for supervisor harassment that conflicted with that recommended by the original E.E.O.C. Guidelines. It argued that employers that have an express policy against sexual harassment and that have implemented a procedure specifically designed to resolve harassment claims generally should not be held liable for intangible harassment when the victim has not taken advantage of the grievance procedure. See id. (quoting the E.E.O.C.'s amicus brief at 23). An employer could still be liable under the agency's standard if it has "actual knowledge" of a sexually hostile environment. Actual knowledge can be inferred from the filing of a complaint through the employer's harassment procedure or from management's knowledge of the particular harassment at issue. Id. The employer could also be liable if the harassment victim had no reasonably available avenue for making her complaint known to management. Id. Future harassment victims, therefore, cannot even rely on the E.E.O.C. to enforce its own standard.

70 42 U.S.C. $\S 2000(\mathrm{e})-5(\mathrm{~g})(1982)$.

${ }^{71} I d$. $\S 2000(\mathrm{e})-5(\mathrm{k})$.

72 Note, supra note 12, at 105 (quoting Albemarle Paper Co. v. Moody, 422 U.S. 405,418 (1975)). 
Although equitable relief can encompass a wide range of remedies-including injunctions, declaratory relief, and monetary awards ${ }^{73}$-federal courts have construed the language of Title VII to exclude any award of compensatory or punitive damages. ${ }^{74}$ Thus, if a female worker is fired for refusing to comply with her employer's demands for sex, the court may order reinstatement with backpay and other lost economic benefits, ${ }^{75}$ enjoin the employer from causing or permitting future harassment, order the employer to take affirmative steps to eliminate sexual harassment and to better deal with employees' complaints, ${ }^{76}$ and award reasonable attorneys' fees.

If an employer is found liable for intangible harassment, relief is necessarily limited to injunctions or orders to take affirmative action; attorneys' fees may be granted as well. ${ }^{77}$ The court does not need to order reinstatement: by definition, intangible harassment means that the victim has not been fired but rather has been forced to work in a hostile environment.

73 See D. Dobbs, Handbook on the LAw of Remedies § 2.1, at 24-27 (1973). At common law, the English Court of Chancery was authorized to issue "coercive," "restitutionary," and declarative relief as the Chancellor deemed appropriate. Id. at 25.

${ }^{74}$ See, e.g., Richerson v. Jones, 551 F.2d 918, 926-27 (3d Cir. 1975) (citing Albemarle Paper Co. v. Moody, 422 U.S. 405, 419 n.11 (1975) (pointing out that Title VII was modeled after the National Labor Relations Act, which does not permit punitive damages); Reid v. Memphis Pub. Co., 369 F. Supp. 684, 690 (W.D. Tenn. 1973), affd in part on other grounds, rev'd in part on other grounds, 521 F.2d 512 (6th Cir. 1975), cert. denied, 429 U.S. 964 (1976); see also B. SchleI \& P. Grossman, EMPLOYMENT Discrimination LAw 1452 \& nn. 153-56 (1983) (the reader is referred to cases cited therein). But see Claiborne v. Illinois Cent. R.R., 401 F. Supp. 1022, 1026 (E.D. La. 1975), affd in part, vacated in part, 583 F.2d 143 (5th Cir. 1978), cert. denied, 442 U.S. 934 (1979) ("[P]unitive damages would further the aims of Title VII by deterring violations and by encouraging plaintiffs to seek relief by increasing their recovery . . . ."); Humphrey v. Southwestern Portland Cement Co., 369 F. Supp. 832 (W.D. Tex. 1973), rev'd on other grounds, 488 F.2d 691 (5th Cir. 1974) (awarding damages under Title VII for mental anguish and loss of job experience). In addition, some federal courts of appeal have suggested that an award of nominal damages accompany attorney's fees. See Katz v. Dole, 709 F.2d 251, 253 n.1 (4th Cir. 1983); Henson v. City of Dundee, 682 F.2d 897, 905-06 \& n.12 (11th Cir. 1982); Joshi v. Florida State Univ., 646 F.2d 981, 991 \& n.33 (5th Cir. 1981), cert. denied, 456 U.S. 972 (1982).

${ }^{75}$ See, e.g., Albemarle Paper Co. v. Moody, 422 U.S. 405, 419-21 (1975) (backpay awarded to make the employee whole).

to See, e.g., Bundy v. Jackson, 641 F.2d 934, 948 n.15 (D.C. Cir. 1981) (recommending to the district court appropriate language for injunctive relief).

27 See, e.g., Morgan v. Hertz Gorp., 542 F. Supp. 123, 128 (W.D. Tenn. 1981), affd, 752 F.2d 1070 (6th Cir. 1984) (enjoining corporate agents and employees from making sexually insulting remarks to female workers); see also Bundy, 641 F.2d at 946 n.12 (pointing out that reinstatement and backpay are "irrelevant" to a case of intangible harassment). 


\section{B. The Inadequacy of Title VII}

Federal law provides important remedies aimed at the elimination of employment discrimination. Title VII alone, however, does not adequately combat the devastating effect of sexual harassment on the individual worker. The limits that the statute imposes on liability completely bar relief in many instances where severe harassment has occurred. For example, because the statute applies only to employers with fifteen or more employees, ${ }^{78}$ a victim of harassment in a smaller commercial enterprise receives no protection under federal antidiscrimination law.

Even when a court does find an employer liable for harassment, Title VII's remedies are often inadequate. A plaintiff cannot rely on the statute's equitable relief provisions to compensate her for lost earning capacity or for nonpecuniary harm such as severe emotional distress or physical injury. ${ }^{79}$ Moreover, if an employee prevails in a lawsuit, the work environment may become so hostile and debilitating, and relations with coworkers or supervisors so strained, that an injunction or reinstatement under Title VII would be unwanted and perhaps counterproductive. ${ }^{80}$ Finally, although a major objective of Title VII is to prevent future employment discrimination, ${ }^{81}$ punitive damages-a powerful economic deterrent-are unavailable no matter how malicious or harmful the harassment may have been. ${ }^{82}$ Title VII correctly treats harassment as discrimination but fails to address the full impact of such conduct on the individual worker.

The severe personal harm that sexual harassment often inflicts demonstrates the need for the kind of relief provided in tort law. As one

${ }^{78}$ See 42 U.S.C. $\$ 2000(e)(b)(1982)$ (defining "employer" for purposes of statute). See supra note 41 .

70 See supra note 74 and accompanying text; see also Note, supra note 12, at 107 (noting that no compensatory relief is available for coworker harassment).

80 See Andrews, supra note 4, at 142-43:

The effectiveness [of an injunction prohibiting sexual harassment] . . . is questionable. It is suggested that plaintiffs and defendants are not usually the "best of friends" after a lawsuit. But rather, after the termination of a lawsuit, plaintiffs and defendants express hostility towards one another .... This type of employment atmosphere would seem to facilitate verbal abuse or possibly some other retaliatory action. . . .

Compensation for sexual harassment should conform to the realities of the situation. It may be unreasonable to expect a sexually harassed victim to return to a job at which she experienced sexual harassment.

82 See supra text accompanying note 72 .

82 See supra note 74 and accompanying text. 
court observed, Title VII's equitable remedies

fail to capture the personal nature of the injury done to a wrongfully discharged employe [sic] as an individual and the remedies provided by the statutes fail to appreciate the relevant dimensions of the problem. Reinstatement, backpay and injunctions vindicate the rights of the victimized group without compensating the plaintiff for such personal injuries as anguish, physical symptoms of stress, a sense of degradation, and the cost of psychiatric care. Legal, as well as equitable remedies are needed to make the plaintiff whole. ${ }^{83}$

\section{The Inadequacy of Traditional Tort Law}

Tort law may be able to provide more complete recovery when the harm inflicted by sexual harassment requires relief beyond the scope of Title VII. Compensatory damages for pain and suffering traditionally are awarded for "virtually any form of conscious suffering, both mental and physical."84 Relief for the invasion of a dignitary interest is also available under such rubrics as assault, battery, and outrage; these theories recognize the wrong as a damage in and of itself. ${ }^{85}$ Special damages may also be recovered for loss of time, reputation, and emotional peace. ${ }^{86}$ In addition, tort law could provide a stronger deterrent in the form of punitive or exemplary damages. Such an award usually is based on the defendant's "culpable state of mind," so that proof of malicious conduct would justify imposing punitive damages on the employer. ${ }^{87}$ Some courts, however, have also awarded punitive damages when the actor has clearly abused a position of power, even if no guilty motive can be shown. ${ }^{88}$ As a supplement to Title VII, a tort theory of

${ }^{83}$ Holien v. Sears, Roebuck \& Co., 298 Or. 76, 97, 689 P.2d 1292, 1303-04 (1984) (reversing dismissal of common law claim of wrongful discharge); see also Andrews, supra note 4, at 147-48 (Because a victim's psychological and physical suffering does not constitute economic loss within the scope of Title VII's equitable relief, the statute fails to consider the mental anguish and outrageousness of workplace harassment.).

84 D. DoBbS, supra note $73, \S 8.1$, at 544 . Dobbs notes, however, that "substantive law may exclude recovery for mental pain in limited circumstances," as it might in an instance where there is no physical impact. Id. at 544-45.

85 See id. § 7.3, at 530-31; see also Warren \& Brandeis, The Right to Privacy, 4 HARv. L. REv. 193 (1890). If the plaintiff's harm is a legal injury, "the elements for demanding redress exist, since already the value of mental suffering, caused by an act wrongful in itself, is recognized as a basis for compensation." Id. at 213.

${ }^{88}$ See D. Dobss, supra note 73, § 7.3, at 531.

87 Id. $\S 3.9$, at 206.

${ }^{88}$ See $i d$. $\& 3.9$, at 206-07 $\mathrm{nn} .14-21$ (the reader is referred to cases cited therein). Allowance of punitive damages on the basis of this special kind of conduct 
recovery would offer a form of relief directly applicable to the personal impact of sexual harassment. ${ }^{89}$

Despite the need for relief for sexual harassment, the traditional theories of recovery in tort are ill-suited to the personal harm that results from workplace harassment. A fundamental reason for this inadequacy is that only in recent years has harassment been recognized as a legally actionable wrong. Tort law cannot provide a precedent for a legal approach to sexual harassment in modern society because traditional theories simply do not conform conceptually "to the social reality of men's sexual treatment of women. . . Although the facts of sex discrimination have a long history in women's suffering, the prohibition on sex discrimination as such lacks a common-law history." "90

Consequently, traditional tort theories continue to produce unsatisfying results when courts attempt to find grounds on which to grant relief. Although some theories have enabled victims to recover for their injuries, doctrinal restrictions have severely limited the possibility of finding a basis for liability in tort. A survey of commonly used theories demonstrates the inadequacies of each, especially in the absence of a termination of employment or the infliction of physical harm. ${ }^{91}$

rather than on the basis of the defendant's mental state, would be entirely consistent with the idea that punitive awards should serve the purpose of encouraging suit by the plaintiff as a "private attorney general" on issues of special importance.

Id. $\S 3.9$, at 207.

${ }_{89}$ See Shaffer v. National Can Corp., 565 F. Supp. 909 (E.D. Pa. 1983) (recognizing that a tort claim was necessary to supplement the state antidiscrimination statute, which generally provided an exclusive remedy when invoked). Injunctions, reinstatement, and backpay further the government's interest in "eradicating targeted forms of discrimination." Id. at 914 . In contrast, "[ $\mathrm{t}$ ] he tort of intentional infliction of emotional distress vindicates the personal interest of freedom from intentionally imposed mental anguish. Damages, both compensatory and punitive, provide the remedy for this wrong." Id.

It has been argued that a common law action against an employer should be considered an alternative, rather than a supplement, to a Title VII claim. See, e.g., Wald, Alternatives to Title VII: State Statutory and Common-Law Remedies for Employment Discrimination, 5 HARv. WOMEN's L.J. 35, 38-40, 44-46 (1982) (arguing that administrative delays, narrow statutory relief, and growing restrictions in judicial interpretations of Title VII render state claims potentially more successful than pendent or separate claims under state and federal law). The specific problems of pendent jurisdiction, state statutory preclusion, and administrative complexities will not be addressed in this Comment.

90 C. MACKInNon, supra note 1, at 161; see also supra note 35 (discussing early tort cases of sexual harassment).

o1 Other theories of recovery that may provide the basis for a harassment claim include defamation, fraud or misrepresentation, and wrongful discharge. These torts, which have a very limited scope, will not be addressed in this Comment. 


\section{A. Assault and Battery}

Liability for assault requires a showing that (1) the actor intended to cause harmful or offensive physical contact, and (2) the victim was put in apprehension of such conduct. ${ }^{92}$ This theory is intended to protect an individual's right to be free from "apprehension of a harmful or offensive contact"; any act that creates such apprehension is a tortious assault, even in the absence of physical contact. ${ }^{93}$ Verbal abuse generally is not actionable unless other conduct or circumstances can be shown to have caused "reasonable apprehension" of imminent contact. $^{.94}$

Battery consists of a harmful or offensive contact that is offensively caused..$^{98}$ Liability requires a showing of intent to touch but not necessarily to harm. Thus, regardless of the actor's specific purpose, battery may involve offensive, insulting, or physically harmful contact. Since apprehension of unwanted physical contact often accompanies the actual touching, a plaintiff frequently may bring an action under claims of both assault and battery.

In the context of sexual harassment, these two theories are useful as long as the victim has either experienced or expected offensive or harmful physical contact. ${ }^{96}$ For example, in Skousen $v . ~ N i d y,{ }^{97}$ a sixtyfive year old caretaker in a trailer park prevailed in a suit against her employer for assault and battery. The park owner repeatedly had attempted to seduce the woman by touching her in a sexual manner and, on several occasions, assaulting her violently. ${ }^{88}$ Recognizing the need to provide relief for both the mental and physical consequences of the employer's conduct, the Arizona Supreme Court upheld an award of compensatory and punitive damages. ${ }^{99}$

92 See Restatement (SECOND) OF ToRTs § 21 (1965); see also Rogers v. Loews L'Enfant Plaza Hotel, 526 F. Supp. 523, 529 (D.D.C. 1981) (sexual harassment case relying on Restatement to define assault and battery).

os See Vietnamese Fishermen's Ass'n v. Knights of the Ku Klux Klan, 518 F. Supp. 993, 1012 (S.D. Tex. 1981) ("It is an assault to hold a weapon in a threatening position, or to surround an individual with a display of force.") (citing W. Prosser, HANDBOOK OF THE LAW OF TORTS $\S 10$ (4th ed. 1971)).

94 See Restatement (SECOND) OF TORTS § 31 (1965); see e.g., Johnson v. G.M. Acceptance Corp., 228 F.2d 104 (5th Cir. 1955) (per curiam) (abusive and insulting language not actionable).

so See Restatement (SECOND) of Torts $\S \S 13,18$ (1965); see also C. MACKINNON, supra note 1 , at 165 (unwanted sexual touching historically considered tortious as battery, assault, or infliction of emotional distress).

96 See Rogers v. Loews L'Enfant Plaza Hotel, 526 F. Supp. 523, 529 (D.D.C.

1981); C. MacKinnon, supra note 1, at 165.

90 Ariz. 215, 367 P.2d 248 (1961).

98 See id. at $216-17,367$ P.2d at 249 .

92 See id. at 219,367 P.2d at 250. 
Unless the harassment involves at least a threat of imminent physical touching, however, the theories of assault and battery cannot provide a basis for liability. Consequently, these doctrines are useless when the alleged harassment consists, for example, of a daily barrage of sexual insults, although the worker suffers severe mental anguish. Furthermore, no liability exists on these grounds even if the employee is threatened with termination of employment. When a hostile work environment or a demand for sexual favors lacks an explicit physical threat, a different theory of recovery is necessary.

\section{B. Intrusion}

Under the Restatement (Second) of Torts, the tort of intrusion is defined as an encroachment, "physically or otherwise, upon the solitude or seclusion of another or his private affairs or concerns .... if the intrusion would be highly offensive to a reasonable person." 100 Despite the broad language of the Restatement, some courts narrowly define intrusion in physical terms, similar to trespass. So construed, recognition of the tort is "directed to protecting the integrity and sanctity of physical areas a person would naturally consider private and off limits to uninvited, unwelcomed, prying persons."101

In Cummings v. Walsh Construction Co., ${ }^{102}$ the trial court dismissed an intrusion claim in which a female worker employed by the construction company alleged that a plant foreman had intimidated her into having sexual relations with him. ${ }^{103}$ Under Georgia law, liability for intrusion required proof that the defendant's conduct was "unwanted, uninvited, and unwarranted."104 Since Walsh did not physically resist her supervisor's advances, the court determined that she was willing to have sex with him: "It is plain that plaintiff had other courses of action but that she did not avail herself of them. . . . [She] had the alternative of outright refusal. She did not choose that path, and in so doing, waived whatever right she had as to her personal seclusion or solitude."105 The court did not consider the possibility that Walsh may have been economically coerced into having sex with her supervisor. Apparently the implicit threat of termination of employment, which unquestionably accompanied the foreman's demands, did

100 Restatement (Second) of Torts $\S$ 652B (1965).

101 Cummings v. Walsh Constr. Co., 561 F. Supp. 872, 884 (S.D. Ga. 1983) (emphasis added).

102561 F. Supp. 872 (S.D. Ga. 1983).

103 See id. at 876.

104 Id. at 884 .

100 Id. 
not suggest that the "sexual encounter" was genuinely "unwanted, uninvited and unwarranted."108

In contrast to the narrow approach in Cummings, other courts have expanded the scope of intrusion to compensate harassment victims even when no physical violation has occurred. In Rogers $v$. Loews L'Enfant Plaza Hotel, ${ }^{107}$ an assistant manager at a hotel restaurant claimed that her supervisor had committed intrusion by frequently telephoning her at home to make sexual advances and to comment about her personal life. ${ }^{108}$ The court refused to dismiss the plaintiff's claim because of her additional allegations of discrimination and other tortious behavior by her supervisor: "[I]n this particular situation, with allegations of sexual harassment in personal, as well as professional life, ... the pleadings are sufficient to indicate an intrusion into a sphere from which plaintiff Rogers could reasonably expect [her supervisor] should be excluded."100

Two years later, the Alabama Supreme Court extended the definition of intrusion to include an employer's invasion of an employee's right to psychological-not merely physical-solitude. In Phillips $v$. Smalley Maintenance Services, ${ }^{110}$ the court found that the employer's continual interrogations about his employee's sex life and his frequent demands for sex had caused the woman to suffer from chronic anxiety, to contemplate suicide, and to require counseling and medication.11 Noting that "[o]ne's emotional sanctum is certainly due the same expectations of privacy as one's physical environment,"112 the court upheld an award of compensatory damages for the woman's medical costs, as well as for her mental anguish.

The Rogers and Phillips decisions demonstrate the flexibility with which one may interpret the scope of intrusive invasion of privacy. In view of the clear need to provide compensation for the victim's pecuniary and emotional harm, the two courts deliberately extended the scope of intrusion beyond its traditional limits in order to find the employers liable for harassment. Whether these cases will establish a new precedent in the interpretation of tort law remains unclear. Furthermore, even if other jurisdictions broaden the scope of intrusion, the extent to which courts will relax the traditional requirements is unpredictable. Finally, some forms of harassment, such as severe intimidation and de-

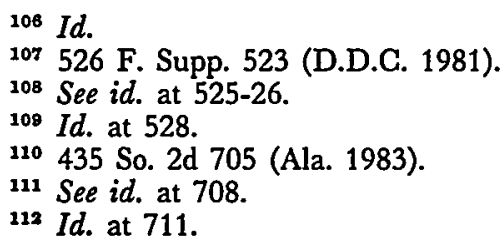


liberate humiliation, could never fall within the rubric of invasion of privacy, if they occur only within the workplace and are limited to topics about which the individual has no expectation of privacy. Although the Rogers and Phillips decisions may heighten the chances of recovery for some plaintiffs, they do not establish a reliable precedent for all victims of workplace harassment.

\section{G. Tortious Interference with Contractual Relations}

Interference with an employment contract occurs when "one intentionally acts to deprive another of an economic benefit."113 Upon proof of (1) actual interference with an employment relationship, and (2) malicious state of mind, a plaintiff may be entitled to both compensatory and punitive damages. ${ }^{114} \mathrm{~A}$ coworker who is ordered to pay punitive damages may not seek indemnification from the employer; thus, the deterrent purpose of punitive damages is advanced by placing a financial burden directly upon the person who engages in harassing conduct. $^{115}$

Unfortunately, however, an action based on this theory is available only under very limited circumstances: the plaintiff cannot be an employee-at-will, ${ }^{118}$ a claim may only be brought against a third party who allegedly interfered with the employment relationship, ${ }^{117}$ and the interfering party's conduct must affect an economic benefit. ${ }^{118}$ As a result, this theory neither imposes liability on an employer ${ }^{119}$ nor enables a plaintiff to recover for mental anguish. ${ }^{120}$

11 Kyriazi v. Western Elec. Co., 461 F. Supp. 894, 950 (D.N.J. 1978).

114 See Restatement (SECOND) OF ToRTs \& 766 (1965): "One who intentionally and improperly interferes with the performance of a contract . . . between another and a third person by ... causing the third person not to perform the contract, is subject to liability to the other for the pecuniary loss resulting . . .."

${ }_{115}$ See Kyriazi v. Western Elec. Co., 476 F. Supp. 335, 341 (D.N.J. 1979) (proceeding to determine damages).

${ }_{116}$ See Cummings, 561 F. Supp. at 883.

117 See id.

118 See Kyriazi v. Western Elec. Co., 461 F. Supp. 894, 950 (D.N.J. 1978).

119 Employer liability is desirable because employers often "tacitly encourage[] [sexual harassment] by deliberately choosing to overlook it," and thus bear significant responsibility for failing to monitor and control the workplace. Id. at 950 . Furthermore, the employer, perceived as a deep pocket, may be the only individual who can provide effective compensation for the aggrieved victim.

130 Damages for mental distress are also barred in actions for breach of contract. See, e.g., Monge v. Beebe Rubber Co., 114 N.H. 130, 316 A.2d 549 (1974) (finding unlawful termination of employment in retaliation against plaintiff for her refusal to date employer). Although the employer had acted maliciously, the court refused to sustain an award for mental suffering. Id. at 134,316 A.2d at 552 . 


\section{Intentional Infliction of Emotional Distress}

Of all the theories of recovery available to a harassment victim, the tort of outrage - the intentional infliction of emotional distress-may be the most successful ground on which to recover for mental harm. The Restatement (Second) of Torts defines the tort of outrage as follows: "One who by extreme and outrageous conduct intentionally or recklessly causes severe emotional distress to another is subject to liability for such emotional distress, and if bodily harm to the other results from it, for such bodily harm."121

For a victim of workplace harassment, this theory of liability provides a particularly strong basis for recovering money damages. The fact that the tort is defined in terms of the actor's conduct virtually ensures an award of punitive damages, which serves as a vital deterrent and provides more complete compensation for the victim. ${ }^{122}$ In addition, under the notion of "parasitic damages" an employer becomes liable for all the consequences of his behavior; thus, a successful claim under this theory may allow a plaintiff to recover for all the direct and indirect effects of sexual harassment. ${ }^{123}$

The absence of a clear definition of outrageous conduct poses the greatest obstacle to recovery under this theory. In contrast to the definitions of other intentional and dignitary harms such as assault, battery, libel, and false imprisonment, the term "outrage" does not refer to a specific type of behavior. ${ }^{124}$ The Restatement and its comments offer an extremely vague standard for judicial evaluation of harassment claims:

Liability has been found only where the conduct has been so outrageous in character, and so extreme in degree, as to go beyond all possible bounds of decency, and to be regarded as atrocious, and utterly intolerable in a civilized community.

\section{Restatement (SeCOND) OF TORTS § 46(1) (1965). \\ 122 Givelber points out:}

The tort of outrageousness furthers the goals typically associated with the doctrine of punitive damages: (1) punishment of the defendant both as a deterrent to future misdeeds by the defendant and as ethical retribution against the defendant for social transgressions, (2) deterrence of others through the example made of defendant, (3) law enforcement in the sense of providing encouragement of the plaintiff to sue to redress societal wrongs, (4) complete compensation of the plaintiff through the provision of additional funds with which to pay the attorney, and (5) a reaffirmation of societal values.

Givelber, The Right to Minimum Social Decency and the Limits of Evenhandedness: Intentional Infliction of Emotional Distress by Outrageous Conduct, 82 Colum. L. REv. 42, 54 n.63 (1982).

${ }_{123}$ See G. MACKInNon, supra note 1 , at 167.

124 See Givelber, supra note 122, at 51-52. 
Generally, the case is one in which the recitation of the facts to an average member of the community would arouse his resentment against the actor, and lead him to exclaim, "Outrageous!"128

As a flagrant violation of public policy, sexual harassment should be recognized as outrageous per se. The Restatement explains that " $[t]$ he extreme and outrageous character of the conduct may arise from an abuse by the actor of a position, or a relation with the other, which gives him actual or apparent authority over the other, or power to affect his interests." ${ }^{126}$ Sexual harassment provides a mechanism for economic coercion in the employment context. ${ }^{127}$ Federal antidiscrimination law demonstrates government intolerance for this infringement on civil rights. Thus, the severe misuse of power inherent in sexual harassment justifies a finding of outrageousness.

The threat of economic coercion in sexual harassment, viewed as a consequence of the inequality inherent in the employment relationship, has in fact led several courts to sustain sexual harassment claims under the tort of outrage. ${ }^{128}$ In these cases, the abuse of power that is unique to sexual harassment distinguishes a plaintiff's allegations from other situations of oppression in the workplace. ${ }^{129}$ For example, the Cummings court determined that an employee-at-will could bring a claim of outrageous conduct even if she was barred from alleging wrongful discharge, because an employer may never act beyond the scope of authority: "[I]t may have been within the power of defendant to fire plaintiff regardless of the reason, but [d] efendant does not have the authority to intentionally injure her emotionally." "130

128 Restatement (SECOND) OF TORTs § 46 comment d (1965). In response, Givelber remarks: "Outrageous conduct, these comments tell us, is conduct that is outrageous." Givelber, supra note 122 , at 53.

${ }^{128}$ Restatement (SeCond) of Torts $\$ 46$ comment e (1965).

127 See supra notes 27-34 and accompanying text.

128 See, e.g., Shaffer v. National Can Corp., 565 F. Supp. 909 (E.D. Pa. 1983) (employer's creation of an oppressive workplace atmosphere caused severe emotional distress); Vegh v. General Elec. Co., 34 Fair Empl. Prac. Cas. (BNA) 135 (E.D. Pa. 1983) (allegations of unwanted sexual advances, verbal and physical conduct sufficient to establish claim for relief); Rogers, 526 F. Supp. 523 (abusive language and physical advances from a direct supervisor); Rice v. United Ins. Co. of America, 465 So. 2d 1100 (Ala. 1984) (pattern of outrageous acts by employer and supervisor sufficient to support claim of intentional infliction of emotional distress); Howard Univ. v. Best, 484 A.2d 958 (D.C. 1984) (allegations of sexual harassment by dean stated a cause of action for intentional infliction of emotional distress).

129 See, e.g., Cummings, 561 F. Supp. at 882; Rogers, 526 F. Supp. at 531; Howard Univ., 484 A.2d at 977.

130 Cummings, 561 F. Supp. at 882. 
In Howard University v. Best, ${ }^{131}$ a female professor whose contract had not been renewed alleged that a male dean's sexual advances and deliberate creation of a hostile work environment not only had resulted in her termination of employment but also had caused her to develop hypertension and to require counseling. ${ }^{132}$ The District of Columbia Court of Appeals, upholding the plaintiff's tort claim, focused in particular on the close relationship between outrageous conduct and the violation of public policy:

Recognizing that women suffer sexual harassment in the workplace, based on outmoded sexual stereotypes and male domination of subordinate female employees, we reject the view, articulated by the trial court, that, as a matter of law, the degrading and humiliating behavior herein detailed was at worse a "social impropriety" which did not amount to the intentional infliction of emotional distress. ${ }^{133}$

As these cases suggest, sexual harassment in the workplace should be regarded as outrageous because such behavior is an unacceptable abuse of power. In practice, however, most courts decide on a case-by-case basis what constitutes extreme and outrageous conduct. Consequently, recovery under the theory of intentional infliction of emotional distress depends on a jurisdiction's standards, rather than on a recognition of the inherently coercive nature of the conduct.

Recent decisions reveal inconsistent attitudes regarding the severity of sexual harassment. As discussed above, some claims of outrage have survived preliminary motions. ${ }^{134}$ In other jurisdictions, however, similar claims have been either withdrawn or dismissed as a matter of law. ${ }^{135}$ In Hooten $v$. Pennsylvania College of Optometry, ${ }^{136}$ for example, the plaintiff claimed that her coworkers constantly had made disparaging remarks to her about her marital status and new role as a mother. They deliberately overloaded her work schedule, forcing her to commit errors and suffer professional embarrassment. When she collapsed one day at work no supervisor came to her aid; she was ultimately dis-

131484 A.2d 958 (D.C. 1984).

132 Id. at 982.

133 Id. at 986. The court pointed out that "the elimination of discrimination within the District of Columbia should have 'the highest priority." "Id. (quoting REport of the Council of the District of Columbia, Committee on Public SERvices AND CoNSUMER AFFAIRS, July 5, 1977, at 3).

134 See supra notes $128-30$ and accompanying text.

135 See, e.g., Guyette v. Stauffer Chem. Co., 518 F. Supp. 521 (D.N.J. 1981) (claim withdrawn before final judgment); Hooten v. Pennsylvania College of Optometry, 601 F. Supp. 1151 (E.D. Pa. 1984) (claim dismissed by court).

1se 601 F. Supp. 1151 (E.D. Pa. 1984). 
charged from her position. ${ }^{137}$ The court decided that, as a matter of law, no jury could construe such conduct to be outrageous. The court stated that to survive a motion for dismissal a claim required allegations of: (1) direct sexual advances, (2) threats of retribution, (3) unconsented physical contact, or (4) sexual references about the employee to other workers. ${ }^{138}$ In apparent disregard for the coercive nature of the coworkers' conduct and employer's implicit consent, the court stated:

While in no way do we wish to mitigate any of the pain and humiliation plaintiff may have suffered, the court does not believe that the alleged conduct ... . [rose] to the level that was so outrageous that it went beyond all bounds of decency. . . . While creating an environment which is oppressive to function within is likely to cause distress it is not the type of action to arouse resentment, by the average member of the community, against the actor. ${ }^{139}$

Thus, the possibility of recovery under this rubric remains uncertain. As one writer observed: "[T]he vitality of this cause of action depends almost entirely on the judicial sensitivity to the true nature of sexual harassment."140 Unless courts fully comprehend the powerful element of coercion in the employment context, it is doubtful that the tort of outrage will provide a reliable basis for relief. A second possible reason for judicial reluctance to extend the intentional infliction of emotional distress beyond its narrow confines may be the concern that a broad definition would create a "flood of litigation."141 Courts may agree that harassment is indeed outrageous but fear that allowing many different kinds of behavior to be actionable would clog the dockets. ${ }^{142}$ Therefore, sexual harassment may not fall within the specific rubric of outrage, but courts may be willing to recognize an independent cause of action for such conduct.

Current tort law thus fails to address the severe personal harm inflicted upon victims of sexual harassment. No single rubric provides

137 See id. at 1153.

138 See id. at 1154.

139 Id. at $1154-55$.

140 Note, Legal Remedies for Employment-Related Sexual Harassment, 64 Minn. L. Rev. 151, 172 (1979).

${ }^{141}$ W. Keeton, D. Dobes, R. Keeton \& D. Owen, Prosser \& Keeton, The LAw of TORTS $\S 4$, at 23 (5th ed. 1984) (The editors state that the courts "always have stood more or less in dread" of such an increase in actions.).

142 See id. at 23-24. "But this is a poor reason for denying recovery for any genuine, serious mental injury. It is the business of the law to remedy wrongs that deserve it ... and it is a pitiful confession of incompetence on the part of any court of justice to deny relief on such grounds." Id. $\S 12$, at 56. 
adequate relief. Even if a worker brought multiple claims against her employer, such a lawsuit would not guarantee complete recovery. The main difficulty with tort law is finding liability at all, under any theory. Although a combination of claims might maximize the kinds of remedies available to a plaintiff, it would prove useless if the employer could not be held liable in the first place. In its present form, therefore, tort law does not provide a satisfactory basis for relief for sexual harassment.

\section{Proposal for a NeW Tort: Sexual Harassment IN THE WORKPLACE}

In creating a debilitating and hostile work environment, sexual harassment inflicts considerable harm on the victim, ranging from physical injury and lost earning capacity to severe emotional distress and other psychological damage. As argued above, neither Title VII nor traditional tort theory afford harassment victims an adequate basis of recovery. The insufficiency of current federal statutory law and state common law demonstrates the importance of establishing a credible theory of liability and a basis for complete legal relief. By deliberately extending the scope of certain torts and criticizing the law's failure to provide recovery in cases of severe injury, several courts apparently have recognized the need to address sexual harassment as a cause of action apart from a civil rights violation. ${ }^{143}$ An independent theory of liability would provide an adequate remedy for the harm suffered by individual employees.

\section{A. Elements of the Proposed Cause of Action}

\section{Definition of Harassment}

For purposes of this proposed theory of recovery, sexual harassment is defined according to the E.E.O.C. Guidelines. ${ }^{144}$ As discussed in Part I, this definition encompasses a broad range of conduct. ${ }^{145}$ The key element is an unreasonable interference with an individual em-

14 See supra notes 84-142 and accompanying text.

14 29 C.F.R. § 1604.11 (1986). See supra text accompanying note 43 . In a recent case in Pennsylvania, the plaintiff's attorney relied on the E.E.O.C. Guidelines' definition for a common-law claim of sexual harassment. The claim survived preliminary motions but, because the case was eventually settled out of court, the theory was never fully tested. See Dorfsman v. C.B.S., No. 84-4634 (E.D. Pa. Sept. 27, 1984) (claims against coworker for sexual harassment and against employer for ratifying and negligently hiring individual defendant).

its See supra notes $42-46$ and accompanying text. 
ployee's right to work in an environment free from sex-based intimidation or hostility.

\section{Reasonable Woman Standard}

Recovery under this theory, as under other theories of dignitary harm, should include both compensatory and punitive damages for all harm proximately resulting from the actor's conduct. To measure a plaintiff's injury and, therefore, the extent of her recovery, a court should apply a "reasonable woman" standard.

A reasonableness standard generally applies to all intentional torts involving emotional harm. For example, recovery under the tort of outrage, which permits relief for emotional distress without accompanying physical injury, requires that the defendant's conduct be outrageous "to a person of ordinary sensibilities." ment, however, applying a completely objective standard of reasonableness would fail to account for the unequal relationship between the sexes, which gives rise to harassment in the first place:

Sex is peculiarly an area where a presumption of gender sameness, or judgments by men of women, are not illuminating as standards for equal treatment, since to remind a man of his sexuality is to build his sense of potency, while for a man to remind a woman of hers is often experienced as intrusive, denigrating, and depotentiating. Making an issue of skin color does not have the same social meaning for blacks as for whites. A corrective "ordinary woman" standard would need to be applied to tort analogies in the discrimination context. ${ }^{147}$

Courts frequently rely on a subjective standard to determine the extent of liability and damages in other areas of law. Liability for assault, for example, is established by what the defendant's behavior "denote[d] at the time to the party assaulted."148 In discrimination cases, the E.E.O.C. Guidelines direct the court to consider "the record as a whole and . . . the totality of the circumstances, such as the nature of

146 Restatement (SeCOND) of Torts $\$ 46$ comment d (1965).

147 C. MAcKinnon, supra note 1 , at 171; see also Goodman, supra note 1 , at 467 (conduct that men find "humorous and innocuous" may be "serious and menacing" to women).

148 C. MacKinnon, supra note 1 , at 167 (quoting W. Prosser, Handbook of THE LAW OF TORTS 41 (1941)); see also Restatement (SECOND) OF TORTS $§ 27$ comment a, at 42 (1965) (stating that even "abnormally sensitive" plaintiffs can recover for assault in some circumstances). 
the sexual advances and the context in which the alleged incidents occurred."148

From the perspective of discrimination law, women and minorities are subjected to a hostile or offensive work environment precisely because they belong to a group that is viewed by society as inferior. Consequently, the race and sex of the harassment victim must be a substantial consideration in evaluating the effect of the defendant's conduct on the plaintiff. For example, when a cosmetic company referred to all its female employees as "girls," a federal court held the company liable for two offenses: sex discrimination against all the women and race discrimination against the black women in particular. ${ }^{150}$ The court evaluated the company's conduct according to its effect on "ordinary black women":

To be addressed as "girl" is inherently more offensive to Negroes than to Caucasians because of the repellant historical images the term understandably evokes. Thus, even though Negro and Caucasian employees are called 'girls' with equal frequency and no discriminatory intent, there will nonetheless be a foreseeable disparate effect. ${ }^{151}$

A compelling example of a reasonable woman standard also appeared in a murder case, in which the court established the standard by which a claim of self-defense should be judged. In State $v$. Wanrow, ${ }^{152}$ the Arizona Supreme Court reversed a conviction for first-degree murder, because the trial court's jury instructions regarding self-defense had erroneously held the female defendant to an objective standard of reasonableness. This misleading standard, which was effectually designed for a confrontation between two men, "constitute[d] a separate and distinct misstatement of the law and, in the context of this case, violate[d] the defendant's right to equal protection of the law."15s The jury should have considered the effects of society's "long and unfortunate history of sex discrimination"154 when it evaluated the woman's conduct and perceptions of danger: "Until such time as the effects of that history are eradicated, care must be taken to assure that our selfdefense instructions afford women to have their conduct judged in light of the individual physical handicaps which were the product of sex dis-

14929 C.F.R. § 1604.11(b) (1986).

${ }^{180}$ See 4 Fair Empl. Prac. Cas. (BNA) 441 (1971).

161 Id.

18288 Wash. 2d 221, 559 P.2d 548 (1977).

153 Id. at 240,559 P.2d at 558-59.

154 Id. at 240, 559 P.2d at 559 (citing Frontiero v. Richardson, 411 U.S. 677, 684 (1973)). 
crimination."158 In a harassment action against an employer, the ordinary woman standard would require the trier of fact to "evaluate the effect of the harasser's conduct on a reasonable woman. For example, an office worker may allege that her employer constantly pinched and grabbed her in the presence of coworkers. The male employees might be unable to perceive that such conduct creates a humiliating and intimidating working environment. Nevertheless, the court should hold the employer liable for harassment, because his behavior is likely to be offensive to the average female employee.

The ordinary woman standard would not impose an unfair double standard on conduct in the workplace. If all employees were bound by a gender-neutral standard, the judge would have insufficient guidance on the question of harassment's effects on women. A standard that supposedly treats men and women the same begs the question: "The same as whom?"156 Under the standard proposed here, the impact of sexual harassment would be properly judged in the context of a society encumbered by a long history of employment discrimination.

\section{B. Employer Liability}

This tort theory would impose an affirmative duty on an employer to prevent and eliminate sexual harassment in the workplace. The employer is "clearly in the best position" to end any form of employment discrimination. ${ }^{182}$ Employers can control the behavior of employees and, indeed, the entire working environment. In an effort to end harassment, employers can implement internal measures, such as an employment policy against harassment and a disciplinary procedure for violations. ${ }^{188}$

Employees must depend on harassment-free working conditions, both for their emotional well-being and for their productivity. Moreover, to maintain an efficient and profitable business, the employer must recognize the economic importance of eliminating any form of em-

${ }^{168}$ Id. at 240,559 P.2d at 559.

186 C. MAcKinnon, supra note 1, at 174. This proposal of a "reasonable woman" standard does not imply that only women are subject to sexual harassment. When appropriate, a "reasonable man" standard should be used for a male plaintiff.

107 Vermeulen, supra note 2, at 292; see also Note, Sexual Harassment Claims of Abusive Work Environment Under Title VII, 97 HARv. L. REv. 1449, 1462 (1984) (arguing that employers are "in the best position to review and evaluate supervisors' conduct"); Note, supra note 12, at 102 (arguing in favor of placing liability "on the party most able to control the work environment and to compensate the victims of sexual harassment").

${ }^{183}$ See 29 C.F.R. $\S 1604.11$ (f) (1986) (suggesting various preventive measures). "Prevention is the best tool for the elimination of sexual harassment." Id. 
ployment discrimination. ${ }^{158}$ The employer's duty under Title VII to refrain from discrimination has been extended, as a practical matter, to include the affirmative duty to investigate and remedy complaints of sexual harassment from employees. ${ }^{160}$ Ultimately, the obligation to prevent and remedy harassment is justified by the extent to which an employer controls the work environment. ${ }^{101}$

The importance of eradicating employment discrimination and the fact that an employer is in the best position to eliminate sexual harassment point to the desirability of holding an employer strictly liable for all harassment in the workplace. If sexual harassment was viewed as occurring within the scope of employment, the doctrine of respondeat superior would justify imposing vicarious liability on the employer for acts of the victim's coworkers. ${ }^{162}$ Under the agency theory of liability, the conduct of supervisors could be directly imputed to the employer, although a principal's liability for an agent's actions generally requires at least implicit ratification of the conduct at issue. ${ }^{163}$ The concept of equitable estoppel, however, could justify liability for harassment by a supervisor even absent employer knowledge or consent. An employer derives benefits from delegating to supervisors the authority to control employees; thus, the employer should be liable for all acts of supervisors when they abuse their positions of authority. ${ }^{164}$ These considerations of fairness and public policy present a persuasive argument in favor of imposing a strict liability standard on the employer.

169 See Vermeulen, supra note 2, at 291.

180 See Munford v. James T. Barnes \& Co., 441 F. Supp. 459, 466 (E.D. Mich. 1977) (employer could be liable for supporting a supervisor's dismissal of a female employee without investigating her harassment complaint).

${ }_{161}$ See M. Shapo, ThE DuTY To Acr 8 (1977) ("[P]ower gives control, which in turn confers duty, the breach of which is conventionally described as negligence. . . . [T] The use of the negligence label in such a case stands for a judgment that there has been a compensable default in the control of power."). Although Shapo specifically refers to an employer's duty to ensure the physical safety of workers, the relationship between power and duty applies directly to sexual harassment; in fact, an employer is probably better able to prevent or eliminate harassment than to eliminate the risk of other kinds of harm, especially accidental physical injury.

162 Respondeat superior is a doctrine of strict liability imposed on a master for the unauthorized torts of her servant if committed while the servant is acting within the scope of employment. H. Reuschlein \& W. Gregory, Agency \& Partnership $\S 52(1979)$.

163 See id. at $\S 32$.

104 See Farley, Sexual Harassment: Critical Review of Legal Cases with General Principles and Preventive Measures, Paper No. 785, Institute for Research in The Behavioral, Economic and Management SCIENCES 14-15 (Jan. 1982); see also Note, supra note 157, at 1461 (arguing that a supervisor empowered to hire and fire is effectually an agent for the employer). 


\section{Workers' Compensation as a Barrier to Tort Actions}

The major obstacle to holding an employer strictly liable for sexual harassment is the workers' compensation system. In implying that harassment arises out of, and in the course of, employment, a strict liability standard invokes the workers' compensation statutes, which bar most tort actions by a worker against her employer.

The general philosophy and distribution of benefits under workers' compensation differ considerably from those of tort law. The primary objective of a tort theory is to redress wrongs that have caused harm. Liability generally depends on fault, and an award of damages is intended to compensate the victim for her loss. In contrast, the workers' compensation laws of a given state provide an economic insurance system for employees. ${ }^{165}$ Liability depends on the extent to which the injury is related to work; the personal fault of an employer or supervisor becomes irrelevant. ${ }^{168} \mathrm{~A}$ specific formula based on the individual's earning capacity determines the amount of damages. ${ }^{167}$

The scope of injuries covered by workers' compensation varies from state to state. Only two states have enacted legislation that specifically addresses nonphysical harm. ${ }^{168}$ Severàl other states have adopted the cumulative action system, whereby a plaintiff is permitted to bring both tort and no-fault claims. ${ }^{169}$ After the claims are settled, the nofault benefits are set off against the damages awarded in the tort action to avoid a windfall recovery. Such a system proves especially useful for sexual harassment claims, which often include both physical and mental harm. ${ }^{170}$ Recovery under this system, however, requires proof of

165 See A. Larson, Workmen's Compensation Laws, § 2.10 (1985); see also Note, Sexual Harassment in the Workplace: A Practitioner's Guide to Tort Actions, 10 Golden Gate U.L. Rev. 879, 908 (1980).

106 See A. LARSON, supra note 165 , at $\S 2.10$.

187 See id. § 2.50 .

${ }^{108}$ Those two states are Wisconsin and California. See CAL. LAB. CoDE $\S 3208-$ 3208.1 (West 1986) (compensable injuries include nonphysical stress or strain caused by one work-related incident or a series of such incidents); Wis. STAT. ANN. $\S 102.01$ (c) (West 1986) (definition of injury includes "mental harm or emotional stress or strain without physical trauma").

${ }^{168}$ See Or. Rev. Stat. § 656.156(2) (1985); Wash Rev. Code AnN. $\S 5124.020$ (1986); W. VA. Code § 23-4-2(b) (1985).

170 Under the cumulative action system, a harassment victim could receive no-fault benefits for physical and mental harm affecting her earning capacity, along with courtawarded compensation for medical costs, pain and suffering, and possibly punitive damages. Her no-fault benefits then would be subtracted from the amount awarded in her tort judgment. See Love, Actions for Non-Physical Harm: The Relationship Between the Tort System and No-Fault Compensation (With an Emphasis on Workers' Compensation), 73 CALIF. L. REv. 857, 860-61 (1985) (discussion includes a hypothetical distinguishing theories of no-fault recovery). 
specific intent; no plaintiff has ever succeeded in a claim for purely nonphysical harm. ${ }^{171}$ Several other states have adopted some form of an alternative action system in which legislative guidelines determine the plaintiff's avenue of relief. ${ }^{172}$ For the most part, however, no-fault compensation laws contain exclusive remedy provisions that preclude most tort actions by an employee against her employer. ${ }^{173}$ In fact, no-fault coverage recently has been expanded to include many kinds of emotional and mental harm. ${ }^{174}$

The scope of workers' compensation becomes a crucial factor in determining an appropriate standard of employer liability for sexual harassment. To hold an employer strictly liable would imply that harassment occurred within the scope of employment. This job-related harm would be covered by workers' compensation, which would then serve to bar a tort action against the employer. Thus, a strict liability standard would become self-defeating when applied to sexual harassment in the workplace.

\section{Liability Outside Workers' Compensation}

To permit an action against an employer, courts must exclude sexual harassment from the coverage of workers' compensation. The courts could generally classify harassment as an injury outside the contemplation of the no-fault system. In addition, one may argue that harassment does not "arise out of" employment for the purposes of the statutes. In this context, a standard of constructive knowledge would impose direct liability on an employer who failed to prevent or eliminate sexual harassment in the workplace.

In some jurisdictions, no-fault compensation statutes specifically deny benefits for injuries involving no job disability, ${ }^{175}$ harm independent of an industrial injury, ${ }^{176}$ harm caused by a specific and nonphysical stimulus, ${ }^{177}$ or intentional torts. ${ }^{178}$ Depending on the jurisdiction

171 See id. at 861-62.

172 See id. at 864-68.

173 Some courts interpret the exclusive remedy clauses literally; most, however, have created exceptions. See id at 868-69.

174 See id. at 871-73.

175 See, e.g., Moll v. Parkside Livonia Credit Union, 525 F. Supp. 786 (E.D. Mich. 1981) (discharged employee with no physical disability not barred from claiming civil rights violations); Columbia Sussex Corp. v. Hay, 627 S.W.2d 270, 279 (Ky. Ct. App. 1981) (slander resulting in no actual injury to plaintiff not covered by workers' compensation and therefore actionable).

${ }_{170}$ See, e.g., Hollman v. Liberty Mutual Ins. Co., 712 F.2d 1259, 1261 (8th Cir. 1983) (bad-faith refusal to pay workers' compensation benefits did not bar valid cause of action in tort).

${ }^{177}$ See, e.g., Cummings v. Walsh Constr. Co., 561 F. S: pp. 872, 880-81 (S.D. 
and the kind of harm at issue, sexual harassment may fall under one of these statutory exceptions. Courts also have held that certain harms, as a matter of public policy, must lie outside the contemplation of workers' compensation laws. In particular, the availability of no-fault benefits for civil rights violations has been viewed as contrary to the legislative intent underlying the entire compensation system. ${ }^{179}$ Sexual harassment, as a clear violation of antidiscrimination law and the general public interest, ${ }^{180}$ should not be recognized as the kind of harm that the workers' compensation scheme was intended to remedy. To permit such a bar to a tort action would undermine the goals of civil rights legislation.

A strong argument can be made for placing sexual harassment outside the scope of employment for the purpose of workers' compensation. Courts have refused to classify certain kinds of harms as occupational risks that an employee must reasonably expect in the workplace. For example, in several jurisdictions the intentional infliction of emotional distress by an employer or supervisor does not constitute a "rational consequence of some hazard related to work."181 The argument for classifying sexual harassment outside the scope of employment is particularly compelling. The relationship between sexual harassment and a woman's employment is entirely different from that between a job-associated risk and the job itself. Harassment arises from an em-

Ga. 1983) (mental trauma not compensable under workers' compensation).

${ }^{178}$ See, e.g., Kissinger v. Mannor, 92 Mich. App. 572, 577, 285 N.W.2d 214, 217 (1979) (action against employer for outrageous conduct by supervisor not barred by workers' compensation because intentional torts outside scope of statute).

179 See, e.g., Renteria v. County of Orange, 83 Cal. App. 3d 833, 841, 147 Cal. Rptr. 447, 451 (1978) (claim of infliction of emotional distress based on racial insults belonged to "an entire class of civil wrongs outside the contemplation of workers' compensation system"); Boscaglia v. Michigan Bell Tel. Co., 420 Mich. 308, 317, 362 N.W.2d 642, 646 (1984) (action for physical, mental and emotional injuries based on Michigan Fair Employment Practices Act and Title VII violations; holding right to compensatory damages under state civil rights' acts would supersede scope of workers' compensation act); Slayton v. Michigan Host, Inc., 122 Mich. App. 411, 417, 332 N.W.2d 498, 501 (1983) (citations omitted) (holding that workers' compensation barred claim for mental anguish "would undercut the legislative scheme to remedy discriminatory wrongs").

180 One court could not "credit the suggestion that the Colorado General Assembly intended to permit licentious behavior under the rubric of workmen's compensation." Bennett v. Furr's Cafeterias, Inc., 549 F. Supp. 887, 891 (D. Colo. 1982) (plaintiff in Title VII action bringing pendent claims for assault, battery, and infliction of emotional distress).

${ }_{181}$ Pryor v. United States Gypsum Co., 585 F. Supp. 311, 314 (W.D. Mo. 1984) (assaults "arising from purely personal and private quarrels" actionable despite workers' compensation statute); see also Iverson v. Atlas Pac. Eng'g, 143 Cal. App. 3d 219, 191 Cal. Rptr. 696 (1983) (employer confining plaintiff against his will); Lagies v. Copley, 110 Cal. App. 3d 958, 168 Cal. Rptr. 368 (1980) (slander intended to cause emotional distress). 
ployer or other man's personal motivation to maintain authority over female workers; in contrast, the occupational hazards covered in most workers' compensation statutes arise from foreseeable risks inherent to the work environment. ${ }^{182}$ Indeed, several courts have recognized that sexual harassment's origins are fundamentally personal, not occupational. ${ }^{183}$

In Bennett v. Furr's Cafeterias, Inc., ${ }^{184}$ a victim of intangible harassment brought suit against her employer for Title VII violations, assault, battery, and infliction of emotional distress. The former management-trainee alleged that on several occasions her supervisor had made unwanted sexual advances and physically assaulted her during business trips. Conceding that the supervisor and employee had acted "in the course of employment"-that is, during the time of employment-the court nonetheless decided that the workers' compensation statutes did not bar the plaintiff"s tort claims: "[I]t would appear to lie outside the bounds of reason to propose that the sort of sexual assault and harassment heretofore described and emotional trauma alleged to have been caused thereby result from risks inherent to the position of 'management trainee.' "18s For similar reasons, the court in Pryor $v$. United States Gypsum Co. ${ }^{188}$ refused to bar a harassed plaintiff's tort claims against her employer. Although most of the victim's coworkers were men, the harassment to which she was subjected could not be viewed as arising out of employment:

[T] The mere fact that the alleged perpetrators were [the plaintiff's] supervisors and employer does not necessarily mean any resulting injuries arose out of employment so as to bring them within the Workers' Compensation law. . . . This court is simply not prepared to say that a female who goes to work in what is apparently a predominantly male workplace should reasonably expect sexual harassment as part of her job. ${ }^{187}$

182 See Note, supra note 165 , at 923.

18s See, e.g., Pryor, 585 F. Supp. at 316 (intentional tort by employer and supervisors); Bennett, 549 F. Supp. at 890 (claim of civil rights violations, assault and battery, and outrageous conduct arising from sexual harassment by employer); Cox v. Brazo, 165 Ga. App. 888, 888-89, 303 S.E.2d 71, 73 (1983) (negligence claim against employer for employing supervisor known to engage in sexual harassment); Hollrah v. Freidrich, 634 S.W.2d 221 (Mo. App. 1982) (action against employer for negligent hiring).

184549 F. Supp. 887 (D. Colo. 1982).

185 Id. at 890.

186 585 F. Supp. 311 (W.D. Mo. 1984).

187 Id. at 316. 
By focusing on the personal nature of harassment and the policy considerations behind the workers' compensation system, courts should recognize that sexual harassment is not an occupational hazard. To treat it as a risk of employment, thereby barring tort actions against an employer, would serve as an implicit legitimization of sexual harassment in the workplace.

A standard of strict liability would bring sexual harassment within the scope of employment. In turn, the coverage of workers' compensation would preclude a tort action against the employer. In order to overcome the obstacle of workers' compensation, as well as to further the remedial and deterrent purposes articulated in this Comment, an employer should be held to a standard of constructive knowledge of harassment. Thus, an employer who negligently, recklessly, or intentionally fails to prevent or remedy detectable harassment in the workplace should be held liable to the victim, whether the actual harasser is a supervisor, coworker, or nonemployee. The effectiveness of this standard clearly requires a liberal interpretation of "constructive knowledge." Employers must be on special notice when contact with employees occurs exclusively through agents, when supervisors exercise authority over employment conditions, when women enter traditionally male fields, when female employees must wear revealing clothing, and when traveling constitutes a substantial part of the job. ${ }^{\text {18s }}$

Due to the wide variety of workers' compensation laws, recovery under the tort of sexual harassment will not be possible in all jurisdictions. If an employer were shielded by an exclusive remedy provision, the plaintiff would be forced to sue the offending coworker or supervisor directly under a traditional tort theory. Nevertheless, in many jurisdictions this new tort could provide a necessary supplement to existing law.

\section{CoNCLUSION}

The cause of action proposed in this Comment would allow a victim of sexual harassment in the workplace to obtain full relief for her harm. The current remedies available under most antidiscrimination statutes fail to address all the harm caused by harassment. Present tort law produces unsatisfactory results as well. The proposed theory of liability, which requires that the standard of recovery be that of a reasonable woman and holds an employer to a standard of constructive knowledge, directly addresses a victim's personal injury.

188 See Vermeulen, supra note 2, at 292 (arguing in favor of a broad standard of constructive knowledge for Title VII violations when harasser is a coworker). 
This cause of action is problematic because, despite the constructive knowledge standard, some workers' compensation statutes may still bar tort actions against an employer. Furthermore, courts may be reluctant to recognize a new theory of recovery, especially in the area of emotional harm. ${ }^{189}$ These concerns demonstrate the desirability of amending Title VII and state antidiscrimination statutes to include both legal and equitable remedies for workplace harassment. ${ }^{190}$

Statutory reform, however, requires public support and usually entails considerable delay. ${ }^{191}$ In light of the need for current relief, affirmative judicial action is necessary. ${ }^{192}$ An independent cause of action for sexual harassment warrants careful consideration.

189 See, e.g., Note, supra note 140, at 177 ("The utility of [a] cause of action is dependent on liberal judicial interpretations of the requisite elements, and of the damages that may be awarded. Judicial conservatism [with respect to sexual harassment] would certainly retard progress toward recompensing victims through the common law.").

190 Several writers advocate the amendment of Title VII and state laws. See, e.g., Note, supra note 157, at 1466-67 (favoring amendment of Title VII for comprehensive remedies); Note, supra note 140, at 179 (proposing a model state statute); Note, supra note 12, at 122 (proposing a modified interpretation or explicit amendment of Title VII to permit compensatory and punitive damages); see also supra note 10 \& accompanying text.

${ }^{101}$ Legislative reform may be especially difficult because sexual harassment does not "engender a high level of opprobrium from all strata of society." See Note, supra note 140, at 180; see also Comment, Sexual Harassment: A Jurisprudential Analysis, 10 CAP. U.L. REv. 607, 613-17 (doubting the effectiveness of proposing criminal sanctions against harassment because society may view them as attempts to legislate morality).

${ }^{102}$ See Goodman, supra note 1, at 465 ("Success in continuing the development of the law will depend to some extent on success in educating judges further about the perniciousness of sexual harassment."); see also W. Prosser, HandBoor of THE LAW OF TORTS $\S 1$, at 7 (4th ed. 1971) (justifying recognition of new torts when conduct is "unreasonable, or socially harmful, from the point of view of the community"); Warren \& Brandeis, supra note 85, at 193 ("Political, social and economic changes entail the recognition of new rights, and the common law, in its eternal youth grows to meet the demands of society."). 


$$
\bullet
$$
$\bullet$ 